PHP LANGUAGE IN TEACHER TRAINING OF INFORMATION TECHNOLOGY

\title{
Jan KUBRICKÝ
}

Abstract: The paper deals with content innovation in teacher training of information technology, paticularly with creating dynamic websites. Basic description of the PHP language is given and arguments for its integration into teaching are discussed.

Keywords: PHP, internet, dynamic www pages, education for information

\section{JAZYK PHP VE VZDĚLÁVÁNÍ STUDENTŮ UČITELSTVÍ INFORMAČNÍ VÝCHOVY}

Resumé: Příspěvek se zabývá otázkou inovace obsahu výuky v rámci přípravy studentů učitelství informační výchovy na vytvárení dynamických www stránek. Představuje základní popis jazyka PHP a východiska jeho zařazení do př́slušné výuky.

Klíčová slova: PHP, internet, dynamické www stránky, informační výchova

Úvod

V dobách internetového počátku a vlastně samotného vzniku technologie www byly všechny internetové stránky statické. Jednoduše řečeno, jak byla stránka napsána, tak byla odeslána do prohlížeče a tak byla také zobrazena. Z Z nejrůznějších důvodů tato statičnost přestávala stačit a proto byla vyvinuta celá řada technologií, které mohou učinit www stránky dynamickými.

Jednou z takových technologií je technologie PHP a její prostředník, skriptovací jazyk PHP. V následující pasáži se tedy blíže zaměříme na něj. Konkrétně na jeho základní popis, výhody a nevýhody, důvody proč zrovna tento jazyk zařadit do vzdělávání budoucích učitelů informační výchovy a v neposlední řadě na jeho implementaci do výuky, jako plnohodnotného předmětu na pedagogické fakultě.

\section{Popis jazyka PHP}

Technologie, které umožní učinit www stránky dynamickými, můžeme primárně rozdělit na klientské a serverové. Klientské technologie fungují na jednoduchém principu. Spolu s HTML stránkou je internetovému prohlížeči odeslán i kus programového kódu a ten je ve správnou chvíli na cílovém počítači zpracován. Příkladem technologií běžících na straně klienta je např́klad JavaScript. Serverové technologie jsou založeny na jiném principu. Když prohlížeč požaduje webovou stránku ze serveru, server tuto stránku nejprve sestaví a pak odešle.

PHP je internetový skriptovací jazyk (serverový) jehož počátky spadají do roku 1994. Vyvinul se z iniciativy jediného člověka a stal se jedním $z$ nejoblíbenějších programovacích jazyků vůbec. Zkratka PHP značí název Personal Home Page (1). Podle zjištěných údajů se PHP v současnosti užívá na řádově desítkách milionů domén po celém světě a v nedávné době vyšla jeho další modernizovaná verze s označením PHP 6.

Obliba jazyka PHP tkví především v jeho jednoduchosti a podobnosti s programovacím jazykem C. Jeho prostřednictvím lze vytvořit "téměř" vše, co souvisí s tvorbou dynamických www stránek. Mezi nejčastější aplikace vytvořené pomocí jazyka PHP patří zejména (2):

- internetové obchody,

- podnikové informační systémy (at' už intranetové nebo internetové),

- diskusní fóra,

- redakční systémy,

- firemní prezentace,

- weboví poštovní či databázoví klienti,

- vyhledávače a katalogy,

- školní weby,

- drobnosti typu počitadla, ankety a mnoho dalších. 


\section{Současné požadavky na učitele}

Dle RVP ZV jsou žáci na druhém stupni ZŠ připravováni k vytváření informačních prezentací, www prezentace nevyjímaje (3). Žáci vytvářejí statické www stránky a to bud' prostřednictvím některého $\mathrm{z}$ WYSIWYG editorů, jako je např. MS FrontPage nebo př́ímo zápisem zdrojového kódu HTML.

Studenti učitelství informační výchovy jsou na tuto skutečnost pečlivě připravováni. Ovšem $\mathrm{v}$ tomto směru je potřeba přihlížet $\mathrm{k}$ novým požadavkům, vzniklým rostoucí informační gramotností žáků, stále př́stupnějším a dostupnějším informacím na internetu a novým nárokům, které jsou na učitele informační výchovy kladeny na současných školách.

V hledisku rostoucí informační gramotnosti žáků a přístupných informací na internetu spatřujeme zvýšený zájem o tvorbu dynamických www stránek. Nadanější žáci sbírají své první zkušenosti s programovacími jazyky na mnoha informačních serverech, které se př́mo zabývají on-line kurzy a výukou těchto technologií. Jejich zájem nejčastěji spočívá v prezentaci vlastních názorů, moderní komunikaci nebo možnostech určité finanční prosperity, která je voblasti www stránek zmiňována snad ze všech stran.

V druhém hledisku, tedy nových požadavcích kladených na učitele informační výchovy spatřujeme povinnost vytvářet a spravovat školní web, který se stává neodmyslitelnou součástí prezentace každé školy a je založen především na údajích v databázi. Učitel v tomto směru už jistě nevystačí se znalostmi s tvorbou klasických statických stránek, ale je nucen vytvořit určité komunikační médium, které může fungovat např́íklad na platformě technologie PHP.

\section{PHP ve vzdělávání učitelů}

Důvodů proč jazyk PHP začlenit do vzdělávání učitelů informační výchovy by se našlo hned několik. $V$ předchozí části jsme nastínili dva nejpodstatnější. Musíme se ovšem nejprve opírat o určité předpoklady.

Věnovat se podstatě a užití jazyka PHP v konkrétních a praktických př́kladech je možno až po zvládnutí základů jazyka HTML. $\mathrm{V}$ tomto bodě $\mathrm{v}$ rámci odborné př́pravy učitelů informační výchovy již není potřeba nic problematizovat. Na pedagogických fakultách se studenti věnují jednak práci ve WYSIWYG editorech, ale učí se též syntaxi jazyka HTML a formy implementace kusu programového kódu skriptovacích jazyků do zdrojového kódu html stránky (7).

Technické požadavky instalace lokálních serverů pro optimální práci a zkoušení výsledků již také není problémem. Zároveň tak umožníme studentům nahlédnout pod pokličku problematiky instalace a správy lokálního serveru.

Zbývá tedy vyřešit poslední a zároveň nejpalčivější otázku. Jakým obsahem a jakými metodami výuku jazyka PHP ve vzdělávání učitelů informační výchovy realizovat. $\mathrm{S}$ ohledem na práci předních odborníků v dané problematice J. Brázy (1) a L. Lacka (8) jsme sestavili základní seznam. Učitel by měl dle našeho názoru získat následující znalosti a dovednosti:

- znát principy funkce webové aplikace, instalace serveru a PHP,

- znát základy jazyka a jeho syntaxi,

- umět vytvářet a užít funkce jazyka PHP,

- umět vytvářet a užít webové formuláře,

- pracovat s datem a časem,

- umět ukládat údaje mimo databázi,

- manipulovat se soubory a

- umět využít databáze.

Neměli bychom zapomínat ještě na další skutečnosti. $\mathrm{Na}$ internetu existuje celá řada volně šiřitelných programů (redakčních nebo publikačních systémů), které umožňují uživatelům i bez znalosti programovacích jazyků vytvářet vlastní dynamické www stránky. I na užití a práci v takových systémech bychom měli učitele připravovat. Tvoří vlastně jednu samostatnou oblast edukační reality v prostředí tvorby dynamických www stránek.

PHP je ve světě internetu a technologie www velmi silným a především slibným nástrojem. Ovšem stává se ještě mocnějším v kombinaci s databází. Nejčastěji se ve spojení s PHP používá databáze MySQL. Ve výuce bychom měli seznámit studenty se základy práce i s tímto nástrojem. Dosáhneme tak téměr̆ kompletní realizace obsahu výuky s jednou z technologií, pro tvorbu dynamických www stránek.

Nastíněný obsah umožní učiteli být žákům odborným rádcem a konzultantem tak, jak se od něj vyžaduje $\mathrm{v}$ moderním pojetí ve vzdělávání. Umožní učiteli též přistoupit $\mathrm{k}$ tvorbě a správě jednodušších redakčních systémů, jako např́klad školního webu nebo výukových www 
stránek. Učitel získá základní potřebné znalosti, které mu umožní se v dané problematice dále vzdělávat, a rozvíjet tak vlastní kompetence.

K možnostem dalšího rozšírení obsahu výuky

Stejně jako v př́ípadě výuky tvorby statických www stránek se obsah výuky inovuje v závislosti na inovacích jazyka HTML nebo příslušného WYSIWYG editoru, i jazyk PHP prochází neustálým vývojem a zdokonalováním. Stejně tak na to musí reagovat obsah výuky. Na zmíněné aspekty je potřeba neustále pamatovat a obsah výuky inovovat.

Konkrétně je nutno $v$ dostatečné míre ověřovat kompatibilitu předchozích verzí s novějšími a nahradit neaktuální části obsahu výuky částmi novými a ověřenými. S ohledem na nové trendy a požadavky také obsah výuky dodatečně rozšířit a zpřesnit. K těmto možnostem můžeme také zařadit rozššření výuky o další moderní technologie v oblasti webu, jako jsou Flash, Ajax a další. Opíráme se tak o pilír na jehož základech je postavena prakticky kompletní problematika tvorby interaktivních www stránek.

\section{Závěr}

Svět $\mathrm{v}$ prostředí www si $\mathrm{v}$ dnešní době nedovedeme bez dynamických www stránek jistě ani představit. Tvoří kompletní sféru existenční komunikace v oblasti ekonomické, zdravotnické, hospodářské, průmyslové, výpočetní, a také též vzdělávací potažmo školské. Prostředí technologie www na internetu je nejrozsáhlejším komunikačním médiem a není možno tuto situaci přehlížet. Učitelé jsou do jisté míry prostředníky komunikace a jsou nuceni využívat tyto moderní formy.

Je potřeba z nich vytvářet odborníky na mnoha polích a v tomto ohledu se jedná o úkol zvláště podstatný. Hodláme jejich př́ípravu rozšsiríit o další rozsáhlý soubor znalostí a dovedností, které ještě do nedávné doby náležely renomovaným odborníkům a profesionálním tvưrcům www stránek. Nicméně nelze se za toto tvrzení schovávat a spousta skutečností nás o tom dnes a denně přesvědčuje.
Učitelé by měli svými znalostmi obrazně řečeno zastřešit žákovy zájmy a pomoci mu rozvíjet své znalosti a dovednosti. A právě voblasti tvorby www stránek to platí dvojnásob. Působí zde totiž aspekt, který více než jinde napomáhá žákům přistupovat $\mathrm{k}$ této problematice dříve, než se s ní seznámí v rámci školního vyučování. Nesnažme se tedy v každém případě nastartovat žákovo vědění, ale spíše ho rozvíjet a popohnat $\mathrm{k}$ dalším metám.

\section{Literatura}

1. BRÁZA, J. PHP 5. 1. vyd. Praha : Grada Publishing, 2005. ISBN 80-247-1146-X.

2. ZAJÍC, P. PHP (1) - Historie a budoucnost [online]. [cit. 2008-11-12]. <URL

http://www.linuxsoft.cz/article.php?id_articl $\mathrm{e}=171>$.

3. Rámcový vzdělávací program pro základní vzdělávání [online]. [cit. 2008-12-12].

<URL http://www.vuppraha.cz/clanek/110>.

4. DOSTÁL, J. Tvorba a správa webu 1 [CDROM]. Olomouc : PdF UP, 2007. ISBN 978-80-244-1936-7.

5. DOSTÁL, J. Tvorba a správa webu 2 [CDROM]. Olomouc : PdF UP, 2007. ISBN 978-80-244-1937-4.

6. DOSTÁL, J. Tvorba a správa webu 3 [CDROM]. Olomouc : PdF UP, 2007. ISBN 978-80-244-1938-1.

7. DOSTÁL, J. Tvorba a správa webu 4 [CDROM]. Olomouc : PdF UP, 2007. ISBN 978-80-244-1939-8.

8. LACKO, L. PHP a MySQL. 1. vyd. Brno : CP books, 2005. ISBN 80-251-0397-8.

9. KROPÁČ, J., CHRÁSKA, M. Výchova $v$ obecně technických předmètech. 1 . vyd. Olomouc : PdF UP, 2004. ISBN 80-2440897-X.

Jan Kubrický, Mgr.

Katedra technické a informační výchovy, Pedagogická fakulta UP, Žižkovo nám. 5, 771 40, Olomouc, tel.č. 068/585635819, email: jankubricky@seznam.cz, http://www.kteiv.upol.cz 